\title{
Mediasi Dalam Tiga Sistem Hukum Dan Perannya di Dalam Terwujudnya Keberhasilan Tujuan Hukum di Indonesia
}

\section{Mediation in Three Legal Systems and Its Role in Realizing the Success of Legal Objectives in Indonesia}

\author{
Taufik Siregar \& Zaini Munawir \\ Program Studi Hukum, Fakultas Hukum, Universitas Medan Area, Indonesia \\ Diterima: April 2020; Disetujui: Agustus 2020; Dipublish: Agustus 2020 \\ *Coresponding Email: zaini@uma.ac.id
}

\section{ABSTRAK}

Penelitian ini meneliti tentang bagaimana proses mediasi menurut PERMA Nomor 1 Tahun 2016, bagaimana tingkat efektititas mediator dalam menyelesaikan perkara di Pengadilan dan bagaimana peran mediasi dalam mewujudkan keberhasilan terwujudnya tujuan hukum di Indonesia. Metode penelitian yang digunakan adalah penelitian yuridis empiris, yaitu penelitian hukum yang dilakukan dengan cara meneliti langsung ke lapangan tempat objek yang diteliti dengan melakukan observasi langsung ke 5(lima) Pengadian Negeri; Medan, Lubuk Pakam, Binjai, Stabat, Tanjung Balai. Data sementara keberhasilan mediasi secara nasional tahun 2017 di Sistem Informasi Penelusuran Perkara (SIPP) MA hanya berkisar 4,14\%. Jumlah itu merupakan gabungan keberhasilan mediasi di lingkungan peradilan umum dan peradilan agama. Data keberhasilan 4,14\% itu berdasarkan data ril yang berhasil ditampilkan dalam menu laporan mediasi di SIPP MA. Sumber data itu ditarik dari SIPP lokal setiap pengadilan di Indonesia. Dari uraian yang penulis kemukakan di atas dapat dipahami bahwa, mediasi merupakan sebuah keniscayaan yang harus diterapkan oleh peradilan dalam rangka menyelesaikan sengketa secara damai, penerapan azas peradilan yang cepat, biaya ringan dan sederhana, serta untuk menekan penumpukan perkara yang terjadi. Data mediasi di persidangan yang berhasil secara nasional tidak sampai 4\%. Mediasi yang diharapkan menjadi solusi alternatif ternyata sepi prestasi. Sebagai Saran Bagi hakim yang ditunjuk sebagai mediator harus merubah mindset bahwa, pelaksanaan mediasi ini bukan sekedar untuk melaksanakan sebuah peraturan an sich, tetapi lebih jauh dari itu adalah agar penyelesaian sengketa antara pihak-pihak yang berpekara dapat dilaksanakan dengan jalan damai berdasarkan kesepakatan.

Kata Kunci: Kecerdasan Emotional, Kinerja Karyawan

\section{ABSTRACT}

This study examines how the mediation process according to PERMA No. 1 of 2016, how the level of effectiveness of mediators in resolving cases in the Court and how the role of mediation in realizing the successful realization of legal objectives in Indonesia. The research method used is empirical juridical research, namely legal research conducted by examining directly to the field where the object under study is by direct observation of the 5 (five) State Procurement; Medan, Lubuk Pakam, Binjai, Stabat, Tanjung Balai. Preliminary data on the success of national mediation in 2017 in the MA Case Search Information System (SIPP) is only around $4.14 \%$. The amount is a combination of mediation success in the general court and religious court. The $4.14 \%$ success data is based on real data that was successfully displayed in the mediation report menu at SIPP MA. The data source was drawn from the local SIPP of each court in Indonesia. From the description above, it can be understood that mediation is a necessity that must be applied by the judiciary in order to settle disputes peacefully, the application of the principle of justice fast, low cost and simple, and to suppress the accumulation of cases that occur. Data on mediation in successful trials nationwide is less than 4\%. Mediation that was expected to be an alternative solution turned out to be devoid of achievement. As a Suggestion For judges appointed as mediators must change the mindset that, the implementation of this mediation is not just to carry out an anich rules, but further than that is that dispute resolution between parties who are parties can be carried out by peaceful means based on agreement.

Keywords: Emotional Intelligence, Employee Performance

How to Cite: Siregar, T. \& Munawir, Z. (2020). Mediasi Dalam Tiga Sistem Hukum Dan Perannya di Dalam Terwujudnya Keberhasilan Tujuan Hukum di Indonesia. Journal of Education, Humaniora and Social Sciences (JEHSS). $3(1): 1-10$ 


\section{PENDAHULUAN}

Indonesia telah memposisikan dirinya sebagai negara hukum (rechtsstaat) yang sistim konstitusi (hukum dasar), tidak bersifat absolutisme (kekuasaan yang tidak terbatas). Meminjam istilah Notohamijoyo "Negara hukum adalah negara yang menempatkan kekuasaan tertinggi pada hukum bukan pada seorang penguasa absolut". Prinsip ini telah berlangsung sejak tahun $1945 \mathrm{di}$ mana pertama kali UUD 1945 disusun dan diberlakukan. Suatu negara yang dalam berkehidupan bernegara, berpemerintahan, dan bermasyarakat, selalu mengacu kepada hukum yang berlaku sebagai pedomannya. Oleh karena itu hukum bertujuan untuk mengatur hubungan antara negara atau masyarakat dengan warganya dan hubungan antar manusia, agar supaya kehidupan di dalam masyarakat berjalan dengan lancar dan tertib dan melindungi kepentingan manusia atau masyarakat, karena dimana-mana bahaya selalu mengancamnya sejak dulu sampai sekarang, baik secara makro maupun secara mikro tanpa membedakan antara manusia yang satu dengan manusia yang lain.

Di Indonesia sendiri hukum dibuat berlandaskan Pancasila serta UUD 1945. Dalam penegakkan hukum di Indonesia memang terjadi beberapa masalah seperti ketidakmampuan suatu lembaga keadilan dalam memberikan keadilan itu sendiri bagi masyarakat. Keadilan dianggap suatu yang sulit untuk didapatkan terutama bagi masyarakat kelas bawah yang sekiranya merupakan golongan yang tidak mampu dalam segi materi. Sekiranya kita dapat melihat fakta yang terjadi di lapangan dengan berbagai macam kasus yang ada dan melibatkan masyarakat kelas bawah. Para penegak hukum antara lain hakim, jaksa, polisi, advokat dan penasihat hukum. Di tangan merekalah terletak suatu beban kewajiban untuk mengimplementasikan suatu prinsip keadilan sebagaimana yang tercantum dalam sila kedua secara optimal dan maksimal.

Hukum bukan sekedar tameng yang diguakan untuk bersembunyi. Tapi, hukum itu sendiri adalah sebuah norma yang harus dipatuhi dan dilaksanakan sesuai dengan ketentuannya. Selain itu, sebagai warga Negara juga harus melakukan pengendalian terhadap hukum itu sendiri, bukan sebagai penonton, tetapi juga sebagai pelaku dalam hukum, tidak peduli ia masyarakat menengah kebawah, keatas, anak-anak, mahasiswa, dan segenap aspek dn lapisan masyarakat juga harus mengerti tentang hukum dan menjunjung tinggi nilai hukum. Jadi, perlunya sosialisasi dan pemberian pengertian dari pemerintah agar masyarakat mengerti hukum. Selain itu juga sebagai warga Negara, haruslah pandai-pandai memilih perwakilan di dalam kelembagaan Negara. Warga Negara tidak memandang dari segi apapun dalam memilih wakil rakyat. Tapi haruslah dengan hati nurani dan dipercaya. Tidak peduli ia kaya atau tidak, tampan dan sebagainya, tapi ia mengerti hukum dan menjung tinggi nilai-nilai yang ada dalam hukum itu sendiri.

Lembaga peradilan, sebagai penegak hukum, harus melaksanakan tugasnya dengan baik. Adili dengan seadil-adilnya. Tidak ada pengadilan secara sepihak. Tegas dalam mengambil suatu keputusan dan mampu memberikan pelayananan yang baik kepada masyarakat. Dalam mengambil keputusan juga harus benar-benar dengan kebijaksanaan yang tinggi. Namun tidak semua proses peradilan itu berjalan lancar. Ada saja hambatannya, dan untuk itu ada mekanisme baru yang ditawarkan dalam konteks hukum Indonesia, yaitu mediasi. Mediasi sebagai metode penyelesaian sengketa secara damai, mempunyai peluang besar untuk berkembang di Indonesia (Hikmah, Minin \& Isnaini, 2019; Fakriyanti dan Syamsul, 2012; Nasution dan Ferry, 2012; Rachmat dan Mahmul, 2013),

Dengan adat ketimuran yang masih mengakar, masyarakat lebih mengutamakan tetap terjalinnya hubungan silaturahmi antar keluarga atau hubungan dengan rekan bisnis daripada keuntungan sesaat apabila timbul sengketa. Menyelesaikan sengketa di pengadilan mungkin menghasilkan keuntungan besar bila menang, namun hubungan menjadi rusak. Menyelamatkan muka (face saving) atau nama baik seseorang adalah hal penting yang kadang lebih utama dalam proses penyelesaian sengketa di negara berbudaya Timur, termasuk Indonesia. Mediasi merupakan salah satu instrumen efektif penyelesaian sengketa non-litigasi yang memiliki banyak manfaat dan keuntungan. Manfaat dan keuntungan menggunakan jalur mediasi antara lain adalah bahwa sengketa dapat diselesaikan dengan win-win solution, waktu yang digunakan tidak berkepanjangan, biaya lebih ringan, tetap terpeliharanya hubungan antara dua orang yang 
bersengketa dan terhindarkannya persoalan mereka yang berlebihan. Oleh karena itu diharapkan bukan hanya ada pihak yang menang atau kalah namun diupayakan dapat melahirkan kesepakatan antara pihakpihak yang bersengketa dengan mufakat dirasakan dapat memenuhi keinginan para pihak tersebut (win-win solution).

Mediasi tidak hanya bermanfaat bagi para pihak yang bersengketa, melainkan juga memberikan beberapa manfaat bagi dunia peradilan. Pertama, bahwa penggunaan mediasi diharapkan dapat mengatasi masalah penumpukan perkara yang diajukan ke pengadilan. Banyaknya penyelesaian perkara melalui mediasi, dengan sendirinya akan mengurangi penumpukan perkara di pengadilan. Kedua, sedikitnya jumlah perkara yang diajukan ke pengadilan akan memudahkan pengawasan apabila terjadi keterlambatan atau kesengajaan untuk melambatkan pemeriksaan suatu perkara untuk suatu tujuan tertentu yang tidak terpuji. Ketiga, proses mediasi dipandang sebagai cara penyelesaian sengketa yang lebih cepat, dan biaya murah dibandingkan dengan proses memutus oleh hakim Berdasarkan uraian tersebut, melatar belakangi penelitian ini dilakukan untuk mengetahui mediasi dalam tiga sistem hukum dan perannya di dalam terwujudnya keberhasilan tujuan hukum di Indonesia.

\section{METODE PENELITIAN}

Penelitian ini merupakan penelitian hukum normatif. Penelitian hukum normative adalah penelitian yang mengacu kepada norma - norma hukum yang terdapat dalam peraturan perundang-undangan dan keputusan Pengadilan.Penelitian hukum normative mencakup penelitian berupa inventarisasi hukum, penelitian berupa usaha -usaha penemuan azas - azas hukum dan dasar falsafah (dogma atau doktrin) hukum positif dan penelitian yang berupa usaha penemuan hukum inconcreto yang sesuai untuk diterapkan guna menyelesaikan suatu perkara hukum tertentu. Dalam metode penelitian hukum normative harus memuat uraian yang berisikan pertama tipe penelitian, kedua pendekatan masalah, ketiga bahan hukum, keempat prosedur pengumpulan bahan hukum, kelima pengolahan dan analisis bahan hukum).

Sumber Hukum Penelitian ini adalah: sumber hukum sekunder dan primer. Untuk sumber hukum primer merupakan bahan yang sifatnya mengikat masalah-masalah yang akan diteliti, seperti UU, Peraturan Pemerintah, Yurisprudensi dan lainnya. Sedangkan Sumber hukum Sekunder merupakan bahan-bahan data yang memberikan penjelasan tentang bahan hukum data primer. Seperti hasil penelitian, karya ilmiah dan sebagainya.

Teknik Pengumpulan Data yang dilakukan adalah pedoman wawancaraserta studi kepustakaan/studi dokumen. Analisis data dilakukan secara kualitatif dimana data - data yang dikumpulkan baik data sekunder, primer serta tertier ditabulasi. Untuk menarik kesimpulan dalam rangka menjawab perumusan masalah dilakukan analisis secara kualitatif dengan memakai metode induktif dan deduktif dengan tujuan agar didapatkan kesimpulan yang menyeluruh (komperehensif) dari setiap permasalahan yang diteliti sehingga dalam analisis tersebut akan ditemukan peran mediasi di dalam terwujudnya keberhasilan tujuan hukum di Indonesia.

\section{HASIL DAN PEMBAHASAN}

\section{Proses Mediasi Menurut PERMA Nomor 1 Tahun 2016}

Terbitnya Peraturan Mahkamah Agung RI (PERMA) No.1 Tahun 2016 tentang Prosedur Mediasi di Pengadilan menunjukkan ada beberapa hal penting yang menjadi pembeda antara PERMA No.1 Tahun 2016 dengan PERMA No.1 Tahun 2008 tentang Mediasi.

Pertama, terkait batas waktu mediasi yang lebih singkat dari 40 hari menjadi 30 hari terhitung sejak penetapan perintah melakukan Mediasi.

Kedua, adanya kewajiban bagi para pihak (inpersoon) untuk menghadiri secara langsung pertemuan Mediasi dengan atau tanpa didampingi oleh kuasa hukum, kecuali ada alasan sah seperti kondisi kesehatan yang tidak memungkinkan hadir dalam pertemuan Mediasi berdasarkan surat keterangan dokter; di bawah pengampuan; mempunyai tempat tinggal, kediaman atau kedudukan di luar negeri; atau menjalankan tugas negara, tuntutan profesi atau pekerjaan yang tidak dapat ditinggalkan. 
Ketiga, hal yang paling baru adalah adanya aturan tentang Iktikad Baik dalam proses mediasi dan akibat hukum para pihak yang tidak beriktikad baik dalam proses mediasi. Pasal 7 menyatakan: (1) Para Pihak dan/atau kuasa hukumnya wajib menempuh Mediasi dengan iktikad baik. 2) Salah satu pihak atau Para Pihak dan/atau kuasa hukumnya dapat dinyatakan tidak beriktikad baik oleh Mediator dalam hal yang bersangkutan:

a. tidak hadir setelah dipanggil secara patut 2 (dua) kali berturut-turut dalam pertemuan Mediasi tanpa alasan sah;

b. menghadiri pertemuan Mediasi pertama, tetapi tidak pernah hadir pada pertemuan berikutnya meskipun telah dipanggil secara patut 2 (dua) kali berturut-turut tanpa alasan sah;

c. ketidakhadiran berulang-ulang yang mengganggu jadwal pertemuan Mediasi tanpa alasan sah;

d. menghadiri pertemuan Mediasi, tetapi tidak mengajukan dan/atau tidak menanggapi Resume Perkara pihak lain; dan/atau

e. tidak menandatangani konsep Kesepakatan Perdamaian yang telah disepakati tanpa alasan sah.

Apabila penggugat dinyatakan tidak beriktikad baik dalam proses Mediasi sebagaimana dimaksud dalam Pasal 7 ayat (2), maka berdasarkan Pasal 23, gugatan dinyatakan tidak dapat diterima oleh Hakim Pemeriksa Perkara. Hal ini ditegaskan dalam Pasal 22 PERMA No.1 Tahun 2016.

Penggugat yang dinyatakan tidak beriktikad baik sebagaimana dimaksud pada ayat (1) dikenai pula kewajiban pembayaran Biaya Mediasi. Mediator menyampaikan laporan penggugat tidak beriktikad baik kepada Hakim Pemeriksa Perkara disertai rekomendasi pengenaan Biaya Mediasi dan perhitungan besarannya dalam laporan ketidakberhasilan atau tidak dapat dilaksanakannya Mediasi.

Berdasarkan laporan Mediator sebagaimana dimaksud pada ayat (3), Hakim Pemeriksa Perkara mengeluarkan putusan yang merupakan putusan akhir yang menyatakan gugatan tidak dapat diterima disertai penghukuman pembayaran Biaya Mediasi dan biaya perkara.

Biaya Mediasi sebagai penghukuman kepada penggugat dapat diambil dari panjar biaya perkara atau pembayaran tersendiri oleh penggugat dan diserahkan kepada tergugat melalui kepaniteraan Pengadilan. Apabila Tergugat yang dinyatakan tidak beriktikad baik sebagaimana dimaksud dalam Pasal 7 ayat (2), dikenai kewajiban pembayaran Biaya Mediasi. Mediator menyampaikan laporan tergugat tidak beriktikad baik kepada Hakim Pemeriksa Perkara disertai rekomendasi pengenaan Biaya Mediasi dan perhitungan besarannya dalam laporan ketidakberhasilan atau tidak dapat dilaksanakannya Mediasi.

Berdasarkan laporan Mediator sebagaimana dimaksud pada ayat (2), sebelum melanjutkan pemeriksaan, Hakim Pemeriksa Perkara dalam persidangan yang ditetapkan berikutnya wajib mengeluarkan penetapan yang menyatakan tergugat tidak beriktikad baik dan menghukum tergugat untuk membayar Biaya Mediasi.

Biaya Mediasi sebagaimana dimaksud pada ayat (3) merupakan bagian dari biaya perkara yang wajib disebutkan dalam amar putusan akhir. Dalam hal tergugat sebagaimana dimaksud pada ayat (1) dimenangkan dalam putusan, amar putusan menyatakan Biaya Mediasi dibebankan kepada tergugat, sedangkan biaya perkara tetap dibebankan kepada penggugat sebagai pihak yang kalah.

Dalam perkara perceraian di lingkungan peradilan agama, tergugat sebagaimana dimaksud pada ayat (1) dihukum membayar Biaya Mediasi, sedangkan biaya perkara dibebankan kepada penggugat. Pembayaran Biaya Mediasi oleh tergugat yang akan diserahkan kepada penggugat melalui kepaniteraan Pengadilan mengikuti pelaksanaan putusan yang telah berkekuatan hukum tetap. Dalam hal Para Pihak secara bersama-sama dinyatakan tidak beriktikad baik oleh Mediator, gugatan dinyatakan tidak dapat diterima oleh Hakim Pemeriksa Perkara tanpa penghukuman Biaya Mediasi.

Ketentuan Pasal 7, Pasal 22 dan Pasal 23 inilah yang nyata berbeda dari ketentuan PERMA No.1 Tahun 2008. "Dan menurut hemat saya disinilah ruh esensial dan indikasi efektifitas proses Mediasi dalam menyelesaikan perkara. Dengan adanya i'tikad baik inilah maka proses mediasi akan berjalan dengan efektif dan efisien. 
PERMA No.1 Tahun 2016 ini pula yang menegaskan kembali peranan MEDIATOR independen untuk berperan lebih aktif dalam menyelesaikan perkara atau sengketa di luar pengadilan, yang kemudian hasil mediasi yang disepakati dapat diajukan penetapan ke Pengadilan melalui mekanisme gugatan.

Lahirnya PERMA No.1 Tahun 2016 ini, dengan harapan ke depan akan lahir MediatorMediator handal dan profesional yang mampu menyelesaikan permasalahan di masyarakat secara damai," kata Thalis.es mediasi menurut PERMA Nomor 1 Tahun 2016

Mediasi di dalam Pengadilan (court annexed mediation) mulai berlaku di Indonesia sejak diterbitkannya Peraturan Mahkamah Agung (PERMA) No. 2 Tahun 2003 tentang Prosedur Mediasi di Pengadilan. PERMA ini bertujuan menyempurnakan Surat Edaran Mahkamah Agung (SEMA) No 1 Tahun 2002 tentang Pemberdayaan Pengadilan Tingkat Pertama dalam Menerapkan Lembaga Damai sebagaimana diatur dalam pasal 130 Herziene Inlandsch Reglemen (HIR) dan pasal 154 Rechtsreglement voor de Buitengewesten (RBg). Pasal 130 HIR dan 154 RBg sebagaimana diketahui mengatur tentang lembaga perdamaian dan mewajibkan hakim untuk terlebih dahulu mendamaikan para pihak yang berperkara sebelum perkaranya diperiksa.

Dengan berlakunya PERMA No 2 Tahun 2003, mediasi bersifat wajib bagi seluruh perkara perdata yang diajukan ke pengadilan tingkat pertama. Untuk mendukung pelaksanaan PERMA No 2 Tahun 2003, pada tahun 2003-2004 Mahkamah Agung melakukan pemantauan pelaksanaan mediasi di empat Pengadilan Negeri (PN) yang menjadi pilot court, yaitu PN Bengkalis, PN Batu Sangkar, PN Surabaya, dan PN Jakarta Pusat. Tujuan pemantauan tersebut adalah untuk mendapatkan gambaran tentang penerapan hasil Pelatihan Sertifikasi Mediator bagi Hakim di empat pengadilan tersebut. Selain pelatihan bagi hakim, juga dilakukan pelatihan bagi panitera di empat pengadilan yang menjadi pilot court tersebut tentang pendokumentasian proses mediasi bagi para Panitera. Dari pelatihan itu, dihasilkan formulir-formulir yang diharapkan menjadi acuan bagi pengadilan-pengadilan lainnya sehingga pendokumentasian dan pengarsipan berkas proses mediasi menjadi seragam.ii Selain empat pengadilan yang menjadi pilot court, Pelatihan Sertifikasi Mediator juga dilakukan di Semarang, ditujukan bagi Hakim di lingkungan Provinsi Jawa Tengah, diikuti dengan pemantauan ke berbagai Pengadilan Negeri Provinsi tersebut.

Pada tahun 2008, PERMA No. 2 Tahun 2003 diganti dengan PERMA No. 1 Tahun 2008. Dalam bagian menimbang PERMA ini disebutkan "bahwa setelah dilakukan evaluasi terhadap pelaksanaan prosedur mediasi di Pengadilan berdasarkan PERMA No. 2 Tahun 2003, ternyata ditemukan beberapa permasalahan yang bersumber dari PERMA tersebut sehingga PERMA No. 2 Tahun 2003 perlu direvisi dengan maksud untuk lebih mendayagunakan mediasi yang terkait dengan proses berperkara di Pengadilan".

Dalam PERMA No. 1 Tahun 2008, sifat wajib mediasi dalam proses berperkara di Pengadilan lebih ditekankan lagi. Ini dapat dilihat dengan adanya pasal yang menyatakan bahwa tidak ditempuhnya proses mediasi berdasarkan PERMA itu merupakan pelanggaran terhadap ketentuan pasal $130 \mathrm{HIR} / 154$ Rbg yang menyatakan putusan batal demi hukum (Pasal 2 ayat (3) PERMA No. 1 Tahun 2008). Sementara Pasal 2 ayat (4) PERMA No. 2 Tahun 2003 menyatakan bahwa Hakim dalam pertimbangan putusan perkara wajib menyebutkan bahwa perkara yang bersangkutan telah diupayakan perdamaian melalui mediasi dengan menyebutkan nama mediator untuk perkara tersebut.

Untuk implementasi dari PERMA No. 1 Tahun 2008, Mahkamah Agung (MA) menunjuk empat Pengadilan Negeri sebagai pilot court, yaitu PN Jakarta Selatan, Bandung, PN Bogor, dan PN Depok. MA juga menerbitkan buku Komentar PERMA No. I Tahun 2008 dan buku Tanya Jawab PERMA No. 1 Tahun 2008 serta video tutorial pelaksanaan mediasi di Pengadilan yang seluruhnya dapat diakses melalui website Mahkamah Agung. Setelah enam tahun berlakunya PERMA No. 1 Tahun 2008, akhirnya Mahkamah Agung Republik Indonesia menerbitkan PERMA No. 1 Tahun 2016. 


\section{Tingkat Efektititas Mediator Dalam Menyelesaikan Perkara Di Pengadilan}

Pada hakekatnya mediator mesti selalu berbentuk netral, dalam pengertian kalau selain tidak memerlihatkan keberpihakan juga disimpulkan jadi penengah yg tidak mempunyai kebutuhan pada hasil akhir atau perjanjian yang diinginkan dibuat lewat sistem mediasi. Sistem memastikan mediator berjalan waktu beberapa pihak ada pada sidang pertama, hakim mewajibkan beberapa pihak ketika itu juga atau paling lama 2 (dua) hari kerja selanjutnya untuk berunding manfaat pilih mediator termasuk juga cost yang mungkin saja muncul karena pilihan pemakaian mediator bukanlah hakim. Jika sesudah periode waktu maksimum beberapa pihak tidak bisa setuju pilih mediator yang diinginkan jadi beberapa pihak harus mengemukakan kegagalan mereka pilih mediator pada ketua majelis hakim. Setelah itu hakim selekasnya menunjuk hakim bukanlah pemeriksa pokok perkara yang bersertifikat pada pengadilan yang sama untuk menggerakkan peranan mediator. Untuk pengadilan sama yg tidak memiliki hakim bukanlah pemeriksa perkara yang bersertifikat, jadi Hakim Pemeriksa Pokok Perkara dengan atau tanpa ada sertifikat yang ditunjuk oleh Ketua Majelis Hakim harus menggerakkan peranan mediator.

Mediasi merupakan cara penyelesaian sengketa secara damai yang tepat, efektif, dan dapat membuka akses yang lebih luas kepada para pihak untuk memperoleh penyelesaian yang memuaskan serta berkeadilan. Perdamaian merupakan cara terbaik dalam menyelesaikan persengketaan di antara pihak berperkara. Dengan perdamaian, maka pihak-pihak berperkara dapat menjajaki suatu resolusi yang saling menguntungkan satu sama lain. Ini dikarenakan, dalam perdamaian, yang ditekankan bukanlah aspek hukum semata, namun bagaimana kedua belah pihak tetap dapat memperoleh manfaat yang sebesar-besarnya dari pilihan-pilihan yang mereka sepakati. Disini terlihat pula bahwa dengan perdamaian, penyelesaian justru lebih mengedepankan sisi humanitas dan keinginan untuk saling membantu dan berbagi. Tidak ada pihak yang kalah maupun menang, yang ada hanyalah pihak yang menang secara bersama-sama. Dalam rangka reformasi birokrasi Mahkamah Agung Republik Indonesia yang berorientasi pada visi terwujudnya badan peradilan Indonesia yang agung, salah satu elemen pendukung adalah mediasi sebagai instrument untuk meningkatkan akses masyarakat terhadap keadilan sekaligus implementasi asas penyelenggaraan peradilan yang sederhana, cepat, dan berbiaya ringan. Ketentuan hukum acara perdata yang berlaku, Pasal 154 Reglemen Hukum Acara untuk daerah luar jawa dan Madura (Reglement Tot Regeling Van Het Rechtwezen In De Gewesten Buiten Java En Madura, Staatsblaad 1927:227) dan Pasal 130 Reglemen Indonesia yang diperbaharui (Het Herziene Inlandsch Reglement, Staatsblaad 1941: 44) mendorong para pihak untuk menempuh proses perdamaian yang dapat didayagunakan melalui mediasi dengan mengintegrasikannya ke dalam prosedur berperkara di Pengadilan.

Proses mediasi di Pengadilan menjadi bagian hukum acara perdata dapat memperkuat dan mengoptimalkan fungsi lembaga peradilan dalam penyelesaian sengketa. Definisi sengketa dalam Kamus Besar Bahasa Indonesia adalah pertentangan atau konflik beberapa pihak mengenai suatu objek permasalahan yang melibatkan kepentingan-kepentingan tertentu di antara para pihak yang terlibat di dalamnya. Menurut Yahya harahap, sengketa sebagai perselisihan yang terjadi diantara pihak-pihak (between contending parties) mengenai suatu hal yang menjadi objek dalam perjanjian antara pihak-pihak tersebut. Sengketa bisa terjadi ketika munculnya perasaan tidak puas oleh salah satu pihak karena terdapat pihak lain yang tidak memenuhi prestasi atau kewajiban-kewajibannya yang telah disepakati dalam butir-butir perjanjian atau persetujuan. Keadaan seperti itu disebut dengan wanprestasi atau tindakan ingkar janji. Wanprestasi dapat berupa :

1. Tidak melaksanakan prestasi sama sekali;

2. Melaksanakan prestasi, tetapi tidak sesuai dengan yang diperjanjikan;

3. Melaksanakan perjanjian, tetapi terlambat atau tidak tepat pada waktunya;

4. Melaksanakan hal-hal yang dilarang dalam perjanjian.

Mediasi adalah cara penyelesaian sengketa melalui proses perundingan untuk memperoleh kesepakatan para pihak dengan dibantu oleh mediator. Mediator adalah hakim atau pihak lain yang memiliki sertifikat mediator sebagai pihak netral yang membantu para pihak dalam proses perundingan guna mencari berbagai kemungkinan penyelesaian sengketa tanpa menggunakan 
cara memutus atau memaksakan sebuah penyelesaian. Ketentuan mengenai prosedur mediasi dalam Peraturan Mahkamah Agung berlaku dalam proses berperkara di Pengadilan baik dalam lingkungan peradilan umum maupun peradilan agama.

Setiap hakim, mediator, para pihak dan/atau kuasa hukum wajib mengikuti prosedur penyelesaian sengketa melalui mediasi. Hakim pemeriksa perkara dalam pertimbangan putusan wajib menyebutkan bahwa perkara telah diupayakan perdamaian melalui mediasi dengan menyebutkan nama mediator. Hakim pemeriksa perkara yang tidak memerintahkan para pihak untuk menempuh mediasi sehingga para pihak tidak melakukan mediasi telah melanggar ketentuan peraturan perundang-undangan yang mengatur mengenai mediasi di Pengadilan. Dalam hal terjadi pelanggaran terhadap ketentuan tersebut, apabila diajukan upaya hukum maka Pengadilan Tingkat Banding atau Mahkamah Agung dengan putusan sela memerintahkan Pengadilan Tingkat Pertama untuk melakukan proses mediasi. Kemudian, Ketua Pengadilan menunjuk mediator hakim yang bukan hakim pemeriksa perkara yang memutus.

Proses mediasi dilakukan paling lama 30 (tiga puluh) hari terhitung sejak diterimanya pemberitahuan putusan sela Pengadilan Tinggi atau Mahkamah Agung. Ketua Pengadilan menyampaikan laporan hasil mediasi berikut berkas perkara ke Pengadilan Tinggi atau Mahkamah Agung. Berdasarkan laporan tersebut, hakim pemeriksa perkara pada Pengadilan Tinggi atau Mahkamah Agung menjatuhkan putusan. Semua sengketa perdata yang diajukan ke Pengadilan termasuk perkara perlawanan (verzet) atas putusan verstek dan perlawanan pihak berperkara (partij verzet) maupun pihak ketiga (derden verzet) terhadap pelaksanaan putusan yang telah berkekuatan hukum tetap, wajib terlebih dahulu diupayakan penyelesaian melalui mediasi, kecuali ditentukan lain berdasarkan Peraturan Mahkamah Agung. Sengketa yang dikecualikan dari kewajiban penyelesaian melalui mediasi meliputi:

a. $\quad$ Sengketa yang diselesaikan melalui prosedur Pengadilan Niaga;

b. $\quad$ Sengketa yang diselesaikan melalui prosedur Pengadilan Hubungan Industrial;

c. Keberatan atas putusan Komisi Pengawas Persaingan Usaha;

d. Keberatan atas putusan Badan Penyelesaian Sengketa Konsumen;

e. Permohonan pembatalan putusan arbitrase;

f. Keberatan atas putusan Komisi Informasi;

g. Penyelesaian perselisihan partai politik;

h. Sengketa yang diselesaikan melalui tata cara gugatan sederhana; dan

i. Sengketa lain yang pemeriksaannya di persidangan ditentukan tenggang waktu penyelesaiannya dalam ketentuan peraturan perundang-undangan.

Sengketa yang pemeriksaannya dilakukan tanpa hadirnya penggugat atau tergugat yang telah dipanggil secara patut. Gugatan balik (rekonvensi) dan masuknya pihak ketiga dalam suatu perkara (intervensi). Sengketa mengenai pencegahan, penolakan, pembatalan dan pengesahan perkawinan. Sengketa yang diajukan ke Pengadilan setelah diupayakan penyelesaian di luar pengadilan melalui mediasi dengan bantuan mediator bersertifikat yang terdaftar di Pengadilan setempat tetapi dinyatakan tidak berhasil berdasarkan pernyataan yang ditandatangani oleh para pihak dan mediator bersertifikat. Pernyataan ketidakberhasilan mediasi dan salinan sah sertifikat mediator dilampirkan dalam surat gugatan.

Berdasarkan kesepakatan para pihak, sengketa yang dikecualikan kewajiban mediasi tetap dapat diselesaikan melalui mediasi sukarela pada tahap pemeriksaan perkara dan tingkat upaya hukum. Proses mediasi pada dasarnya bersifat tertutup kecuali para pihak menghendaki lain. Penyampaian laporan mediator mengenai pihak yang tidak beriktikad baik dan ketidakberhasilan proses mediasi kepada hakim pemeriksa perkara bukan merupakan pelanggaran terhadap sifat tertutup mediasi. Pertemuan mediasi dapat dilakukan melalui media komunikasi audio visual jarak jauh yang memungkinkan semua pihak saling melihat dan mendengar secara langsung serta berpartisipasi dalam pertemuan. Para pihak wajib menghadiri secara langsung pertemuan mediasi dengan atau tanpa didampingi oleh kuasa hukum. Kehadiran para pihak melalui komunikasi audio visual jarak jauh yang memungkinkan semua pihak saling melihat dan mendengar secara langsung serta berpartisipasi dalam pertemuan dianggap sebagai kehadiran langsung. 
Ketidakhadiran para pihak secara langsung dalam proses mediasi hanya dapat dilakukan berdasarkan alasan sah. Alasan sah tersebut meliputi kondisi kesehatan yang tidak memungkinkan hadir dalam pertemuan mediasi berdasarkan surat keterangan dokter; di bawah pengampunan; mempunyai tempat tinggal, kediaman atau kedudukan di luar negeri; atau menjalankan tugas Negara, tuntutan profesi atau pekerjaan yang tidak dapat ditinggalkan. Hal yang paling menjadi dasar yang merujuk pada Perma No 1 Tahun 2016 tentang Prosedur Mediasi di Pengadilan adalah ditetapkannya iktikad baik sebagai salah satu determinan dalam menentukan berhasil tidaknya mediasi. Perma ini tampaknya ingin lebih mendorong kesadaran para pihak berperkara untuk mengubah pola pikirnya dalam menyelesaikan sengketa dengan mengendepankan upaya-upaya perdamaian. Ketentuan tersebut tampaknya didasarkan pada kenyataan bahwa banyak perkara yang dimediasi, terutama di Pengadilan kota-kota besar yang pihak materil principal-nya tidak pernah datang menghadap mediator sekalipun telah dipanggil.

Padahal dapat diketahui bersama bahwa mediasi secara langsung kepada pihak materil jauh lebih maksimal dan kemungkinan tercapainya suatu perdamaian juga lebih besar. Karena itu, dapat dipahami mengapa Perma Mediasi menekankan pentingnya iktikad baik dari pihak berperkara dengan ancaman bahwa jika penggugat tidak beriktikad baik, maka gugatannya dinyatakan tidak dapat diterima. Pasal 7 ayat 1 Perma No. 1 Tahun 2016 tentang Prosedur Mediasi di Pengadilan menekankan kewajiban para pihak berperkara untuk beriktikad baik selama proses mediasi. Jika tidak beriktikad baik, maka gugatannya dinyatakan tidak dapat diterima. Pasal 7 ayat 2 menguraikan hal atau keadaan dimana salah satu atau kedua pihak berperkara dinyatakan tidak beriktikad baik, yaitu:

a. Tidak hadir setelah dipanggil secara patut 2 (dua) kali berturut-turut dalam pertemuan mediasi tanpa alasan sah;

b. Menghadiri pertemuan mediasi pertama, tetapi tidak pernah hadir pada pertemuan berikutnya meskipun telah dipanggil secara patut 2 (dua) kali berturut-turut tanpa alasan sah;

c. Ketidakhadiran berulang-ulang yang mengganggu jadwal pertemuan mediasi tanpa alasan sah;

d. Menghadiri pertemuan mediasi, tetapi tidak mengajukan dan/atau tidak menanggapi resume perkara pihak lain; dan/atau

e. Tidak menandatangani konsep kesepakatan perdamaian yang telah disepakati tanpa alasan sah.

Dalam proses mediasi, terdapat 3 (tiga) tahapan yaitu:

1. Tahap pramediasi

Tahap pramediasi adalah tahap awal dimana mediator menyusun sejumlah langkah dan persiapan sebelum mediasi dimulai. Pada tahap ini, mediaor melakukan beberapa langkah strategis, yaitu membangun kepercayaan diri, menghubungi para pihak, menggali dan memberikan informasi awal mediasi, fokus pada masa depan, mengkoordinasikan para pihak yang bersengketa, mewaspadai perbedaan budaya, menentukan tujuan, para pihak, serta waktu dan tempat pertemuan, dan menciptakan situasi kondusif bagi kedua belah pihak.

2. Tahap pelaksanaan mediasi

Tahap pelaksanaan mediasi adalah tahap dimana para pihak yang bersengketa bertemu dan berunding dalam suatu forum. Dalam tahap ini, terdapat beberapa langkah penting, yaitu sambutan dan pendahuluan oleh mediator, presentasi dan pemaparan kondisi-kondisi faktual yang dialami para pihak, mengurutkan dan mengidentifikasi secara tepat permasalahan para pihak, diskusi (negosiasi) masalah-masalah yang disepakati, mencapai alternatif-alternatif penyelesaian, menemukan butir kesepakatan dan merumuskan keputusan, mencatat dan menuturkan kembali keputusan, dan penutup mediasi.

3. Tahap akhir implementasi mediasi

Tahap ini merupakan tahap dimana para pihak menjalankan kesepakatan-kesepakatan yang telah mereka tuangkan bersama dalam suatu perjanjian tertulis. Para pihak menjalankan hasil kesepakatan berdasarkan komitmen yang telah mereka tunjukkan selama dalam proses mediasi. Pelaksanaan (implementasi) mediasi umumnya dijalankan oleh para pihak sendiri, tetapi pada beberapa kasus, pelaksanaannya dibantu oleh pihak lain. 


\section{Peran mediasi dalam mewujudkan keberhasilan terwujudnya tujuan hukum di Indonesia} berikut:

Tingkat Keberhasilan Mediasi Pada Pengadilan Negeri di Sumatera Utara, dapat diuraikan sebagai

Tabel 1.

Tingkat Keberhasilan Mediasi di Pengadilan Negeri Medan

\begin{tabular}{|l|l|l|l|l|}
\hline No. & Tahun & Jumlah Perkara & $\begin{array}{l}\text { Keberhasilan } \\
\text { Mediasi }\end{array}$ & $\begin{array}{l}\text { Persentase } \\
\text { Keberhasilan }\end{array}$ \\
\hline 1. & 2017 & 553 & 7 & $\mathbf{1 2 6 \%}$ \\
\hline 2. & 2018 & 580 & 5 & $0.86 \%$ \\
\hline 3. & 2019 & 534 & 5 & $0.93 \%$ \\
\hline
\end{tabular}

Tabel 2.

Tingkat Keberhasilan Mediasi Di Pengadilan Negeri Lubuk Pakam

\begin{tabular}{|l|l|l|l|l|}
\hline No. & Tahun & Jumlah Perkara & $\begin{array}{l}\text { Keberhasilan } \\
\text { Mediasi }\end{array}$ & $\begin{array}{l}\text { Persentase } \\
\text { Keberhasilan }\end{array}$ \\
\hline 1. & 2017 & 151 & 3 & $1,98 \%$ \\
\hline 2. & 2018 & 128 & 1 & $0.78 \%$ \\
\hline 3. & 2019 & 134 & 3 & $2.23 \%$ \\
\hline
\end{tabular}

Tabel 3.

Tingkat Keberhasilan Mediasi di Pengadilan Negeri Binjai

\begin{tabular}{|l|l|l|l|l|}
\hline No. & Tahun & Jumlah Perkara & $\begin{array}{l}\text { Keberhasilan } \\
\text { Mediasi }\end{array}$ & $\begin{array}{l}\text { Persentase } \\
\text { Keberhasilan }\end{array}$ \\
\hline 1. & 2017 & 25 & 1 & $4.00 \%$ \\
\hline 2. & 2018 & 40 & 0 & $0.00 \%$ \\
\hline 3. & 2019 & 30 & 0 & $0.00 \%$ \\
\hline
\end{tabular}

Tabel 4 .

Tingkat Keberhasilan Mediasi di Pengadilan Negeri Stabat

\begin{tabular}{|l|l|l|l|l|}
\hline No. & Tahun & Jumlah Perkara & $\begin{array}{l}\text { Keberhasilan } \\
\text { Mediasi }\end{array}$ & $\begin{array}{l}\text { Persentase } \\
\text { Keberhasilan }\end{array}$ \\
\hline 1. & 2017 & 40 & O & $0.00 \%$ \\
\hline 2. & 2018 & 35 & 1 & $2.85 \%$ \\
\hline 3. & 2019 & 25 & 2 & $8.00 \%$ \\
\hline
\end{tabular}

Tabel 7 .

Tingkat Keberhasilan Mediasi Di Pengadilan Negeri Tanjung Balai

\begin{tabular}{|l|l|l|l|l|}
\hline No. & Tahun & Jumlah Perkara & $\begin{array}{l}\text { Keberhasilan } \\
\text { Mediasi }\end{array}$ & $\begin{array}{l}\text { Persentase } \\
\text { Keberhasilan }\end{array}$ \\
\hline 1. & 2017 & 13 & o & $0.00 \%$ \\
\hline 2. & 2018 & 23 & 0 & $0.00 \%$ \\
\hline 3. & 2019 & 17 & 3 & $17.64 \%$ \\
\hline
\end{tabular}

\section{SIMPULAN}

Dari uraian yang penulis kemukakan di atas dapat dipahami bahwa, mediasi merupakan sebuah keniscayaan yang harus diterapkan oleh peradilan dalam rangka menyelesaikan sengketa secara damai, penerapan azas peradilan yang cepat, biaya ringan dan sederhana, serta untuk 触 http://mahesainstitute.web.id/ojs2/index.php/jehss

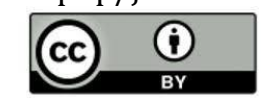


menekan penumpukan perkara yang terjadi. Data mediasi di persidangan yang berhasil secara nasional tidak sampai $4 \%$. Mediasi yang diharapkan menjadi solusi alternatif ternyata sepi prestasi.

\section{DAFTAR PUSTAKA}

Abbas, S, (2009). Mediasi dalam Perspektif Hukum Syariah, Hukum Adat \& Hukum Nasional. Jakarta: Kencana Prenada Media Group

Fakriyanti, dan Syamsul A., (2012), Efektifitas Pengadilan Agama Medan dalam Melakukan Mediasi Sebagai Alternatif Penyelesaian Sengketa Perceraian, Mercatoria, 5 (1): 23-43

Fakriyanti, dan Syamsul A., (2012), Efektifitas Pengadilan Agama Medan dalam Melakukan Mediasi Sebagai Alternatif Penyelesaian Sengketa Perceraian, Mercatoria, 5 (1): 23-43

Modul 3 A, Pengantar Mediasi di Pengadilan Berdasarkan Peraturan Mahkamah Agung RI Nomor 1 tahun 2016 tentang Prosedur Mediasi di Pengadilan, Presentasi oleh Edy Wibowo, Pelatihan dan Pendidikan Sertifikasi Hakim Mediator, (Bogor, Balitbang Kumdil Mahakamah Agung RI, 2016)

Modul 3 B, Administrasi Mediasi di Pengadilan, Presentasi oleh Mohammad Noor, Pelatihan dan Pendidikan Sertifikasi Hakim Mediator, (Bogor, Balitbang Kumdil Mahakamah Agung RI, 2016)

Modul I, Konteks dan Pemahaman Umum Tentang Kedudukan dan Peran Mediasi Dalam Penyelesaian Perkara di Pengadilan, Presentasi oleh Edy Wibowo, Pelatihan dan Pendidikan Sertifikasi Hakim Mediator, (Bogor, Balitbang Kumdil Mahakamah Agung RI, 2016)

Nasution, F.D, dan Ferry A.S., (2012), Penyelesaian Sengketa Perdata dengan Mediasi Menurut Peraturan Mahkamah Agung Nomor 1 Tahun 2008, Mercatoria, 5 (1): 44-55

Nasution, F.D, dan Ferry A.S., (2012), Penyelesaian Sengketa Perdata dengan Mediasi Menurut Peraturan Mahkamah Agung Nomor 1 Tahun 2008, Mercatoria, 5 (1): 44-55

Hikmah, N. Minin, D. \& Isnaini. (2019). Mediasi Sebagai Alternatif Penyelesaian Sengketa Perdata di Pengadilan (Analisis Putusan Nomor. 52/PDT.G/2015/PN.RAP). ARBITER: Jurnal Ilmiah Magister Hukum. 1(2) 2019: 194-201.

Rachmat, O.B., Mahmul S., (2013), Pelaksanaan Mediasi dalam Perkara Perdata Berdasarkan Peraturan Mahkamah Agung Nomor 01 Tahun 2008 di Pengadilan Negeri Stabat, Mercatoria, 6 (2):202-212

Rahmadi, Takdir, Mediasi, (Makalah) disampaikan pada Pendidikan dan Pelatihan Sertifikasi Mediator, Bogor: Balitbang Diklat Kumdil Mahkamah Agung RI, 11 Juli 2013.

Rahmadi, T, (2000). Mediasi: Penyelesaian Sengketa Melalui Pendekatan Mufakat, Jakarta: PT. Raja Grafindo Persada

Umam, K, (2010). Penyelesaian Sengketa di luar Pengadilan, Yogyakarta: Pustaka Yustisia, 2010 